\title{
Considerations for Evaluating 'Good Care' in Canadian Aboriginal Early Childhood Settings
}

\section{Arlene Holland Stairs}

Queen's University

Judith K. Bernhard

Ryerson University

digital.library.ryerson.ca/object/368

Please Cite:

Stairs, A., \& Bernhard, J. (2002). Considerations for evaluating 'good care' in Canadian aboriginal early childhood settings. McGill Journal of Education, 37(3), 309-330.

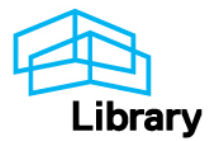




\title{
CONSIDERATIONS FOR EVALUATING'
}

\section{'GOOD CARE'2 IN CANADIAN ABORIGINAL}

\author{
EARLY CHILDHOOD SETTINGS
}

\author{
ARLENE HOLLAND STAIRS Queen's University \\ JUDITH K. BERNHARD Ryerson University \\ WITH ABORIGINAL COLLEAGUES AND INDIGENOUS FEEDBACK ${ }^{3}$
}

ABSTRACT. A request to Arlene and Judith for a critique of Aboriginal Head Start evaluations led to this retrospect and prospect on purposes and processes of early childhood care and education. 'The work has been a multi-log over several years involving indigenous educators and communities, along with others concerned about indigenous developmental goals, authenticity and power in intercultural relationships. We revisit deeply problematic issues in conventional evaluation approaches. We theorize and speculate on alternatives grounded in Aboriginal experiences and values of 'good care' in childhood.

\section{PARAMÈTRES D'ÉVALUATION' DES “ BONS SOINS " DANS LES MILIEUX PRÉSCOLAIRES AUTOCHTONES CANADIENS}

RÉsumé. C'est une demande adressée à Arlene et Judith pour qu'elles fassent une critique des évaluations d'un programme Bon départ autochtone qui a abouti à cette rétrospective et prospective sur les objectifs et les méthodes de soins et d'éducation de la petite enfance. Le projet s'est échelonné sur plusieurs années avec des éducateurs et: des communautés autochtones, et d'autres qui s'intéressent aux objectifs de développement des Autochtones, et à l'authenticité et au pouvoir des rapports interculturels. Nous analysons des éléments hautement problématiques dans les méthodes d'évaluation classiques. Nous théorisons et spéculons au sujet desoptions enracinées dans les expériences autochtones et des valeurs des " bons soiris » dans la petite enfance.

\section{Backgrounding/remembering Retrospect's}

Every paper finally emerging 'in press' has a history, and this one began from the challenges and convolutions irı responding to a request for critique of evaluations carried out in Canadian Aboriginal Head Start (AHS) programs. Head Start was initiated in the United States in 1965 "to help break the cycle of poverty by providing preschool children with a program to meet their emotional, social, health, nutritional and psychological needs" (Commissioner's Office, 2000 , p. v). While cultural and linguistic diversity in US Head Start has been recently celebrated on the basis of "minority" statistics (pp. i, vi-vii), it was in Canada that Head Start programs particular to 
Aboriginal children were initiated in 1995 (Health Canada, 1994, 1995, 1996). The mandate of AHS encompassed the developmental basics articulated in the United States with the re-focused goals of positive Aboriginal self-identity and empowerment of parents, extended family, and the community in the growth of each child - culminating in the production of measurable positive outcomes for Aboriginal children (AHS Subcommittee, 1996, pp. 8-9). Of course the 'positiveness' of such 'outcomes' and their 'measurement' are immensely complex issues, still rife with gaps in conceptualization and practice, and they cry out for the stepping back and cultural-historical meaning-making we just begin to address here.

Historically the Canadian government has colonized the Aboriginal peoples. Those who survived have from the beginning been subject to various educational regimes aimed at assimilation to Euro-white culture and elimination of ties to their own ways of life, including their languages. Without reviewing this disturbing history in detail, we highlight the issue of residential schooling which lasted until the 1960 s - such settings being the most extreme way of eliminating ties between students and their parents and communities (e.g., Grant, 1996; Todd, 1991). Certainly now we see this period as the antithesis of 'good care.'

Around the time of the demise of the residential schools, the Aboriginal peoples of North America (and other minorities) began pressuring for social change, for rights - especially rights to land. With that pressure came a push for Aboriginal control of education and social services. There has been a movement to revitalize Aboriginal languages and values in these settings. Many of the cultural renewal programs were federally funded and, with this government funding, came the issue of standards and 'success' of the programs. Initially, there was a relatively unreflective use of mainstream instruments. Since the mid-1970s and the emergence of national 'multiculturalism' policies (despite indigenous peoples' ambiguous identification with multicultural politics and philosophy), myriad questions of educational program content and evaluation have been raised by Aboriginal leaders and educators.

While the questions being asked here arise from the history of evaluation approaches in Aboriginal early childhood settings (Goulet, DressymanLavallee \& McLeod, 2001, pp. 142-145; Xtria, 2001), these have to be grounded in a context of Aboriginal communities asserting their right to be self-sufficient and self-governing as they assume responsibility for many of the functions that, in the past and still often currently, were/are undertaken by paternalistic governments, scholars, and other outsiders. Euro-North American views of child development have for too long been privileged over Aboriginal visions and values. 
"The knowledge of First Nations traditional and contemporary approaches to raising children and youth and their understanding of their own family dynamics lies within the First Nations People, not with a university program" (Pence, Kuehne, Greenwood-Church, Opekokew \& Mulligan, 1992, p. 17). "Indigenous knowledges are understood as . . . concerning the everyday realities of living . . . imparted to the younger generation by community elders. . . They also refer to ... a direct experience of nature and its relationship with the social world," altogether generating "nuances, contradiction, and contestations in affirming the place of indigenous knowledge in the academy, while maintaining that different bodies of knowledge continually influence each other" (Dei, Hall \& Rosenberg, 2000, fronticepiece). Many organizations contributing to the Canadian Royal Commission on Aboriginal Peoples (RCAP, Vol. 3, 1996) advocated their own control of early care and education (ECE) programs, demonstrated by some outstanding examples offered in the literature and other media, e.g., Tikanagan [Cree for 'cradleboard'] child care agency on a 25,000 squaremile rural reserve in Northern Ontario, formed after provincial services collapsed due to cultural differences and mistrust (Cardinal, 1991); Buffalo Lake AHS in Saskatchewan and a Victoria, BC elementary school, involving Elders in inner-city team teaching with/for children, parents and staff (Driscoll, 1995; Goulet et al., 2001); and the child care centre associated with First Nations House of Learning (University of British Columbia) which obtained a legal exemption enabling multi-age classrooms - the centre had protested the provincial requirement for single-age groupings on the basis that such narrow groupings interfere with the development of children's identity as siblings and community members (Bernhard, Pollard, Eggers-Pierola \& Morin, 2000; Greenwood, 2001). Only with this sense of Aboriginal community and knowledge base does it make sense to discuss evaluation of childcare and educational programs.

\section{DE-COLONIZING/UN-COLONIZING PROS PECTS}

Linda Tuhiwai Smith (2000), a Maori scholar in New Zealand, argues that a new agenda for research must be set in accord with what is referred to in New Zealand as the Indigenous People;' Project. She emphasizes, as have other indigenous and minority groups, that research (embracing without distinction what we label 'evaluation research') must be in accord with and further the needs of the community. She describes the Research Unit for Maori Education as including (a) promotion of Maori research which would 'make a difference,' (b) development of strategies to influence Maori educational policy, and (c) preparation of Maori researchers. Tuhiwai Smith and other indigenous voices converge on several principles of de-/un-colonization central to Aboriginal ECE or other program evaluation. 


\section{Democratizing projects}

Democratizing projects includes the process of reinstating indigenous principles of collectivity. This becomes particularly important in the design of evaluation tools for young children that incorporate the collective values of the local community. In many collectives, the success of the child in the community is interdependent with her development according to mainstream values.

\section{Reframing projects}

Reframing means to define issues in the community's own terms. An example might be the children who do not complete their schooling. Rather than using the term "drop out," Dei (1995) talks of "push out." Once the dropout is reframed as a push-out, the questions asked in evaluation must change dramatically - from asking what academic abilities the person is lacking to examining the failures of institutions in meeting the child's needs.

\section{Questioning purposes}

The two principles above make us dig more deeply into the purposes of AHS and other programs of early childhood care and education, asking what is being evaluated, consciously or not. At least four intertwining visions can be seen for early childhood Aboriginal programs. These encompass the mainstream academic success of children and thus a choice in their futures; the support of Aboriginal families in overcoming poverty and marginalization; the 'coming home' literally and/or figuratively of children being lost to Aboriginal communities both personally and legally (see Kingsolver's poignant story, 1993); and the essential establishment of children's identity valuing and giving expression to Aboriginal cultures. In Stoney Chief John Snow's hopeful words 15 years ago, "We still educate our children for cultural survival" (speech communication, Alberta, 1977). In the proposal of an Inuit school committee (Comité pédagogique, 1974) during the same era, "We absolutely want our children to learn another way almost as much as we want them to learn the Inuit way. For they will have their own ambitions," but "it is a necessity for the Inuit children to learn the Inuit tradition first. ... because once a person forgets ... his thinking would seem to be nowhere. Such a person wouldn't feel at home anywhere, like a lost child" (pp. 5-6). To our knowledge, 'good care' has not been clarified, prioritized, or examined as to the relations among these purposes and so rests in confusion about what currently-favoured evaluation tools are evaluating. This confusion is far more than a technical weakness but gives rise to misinterpretations at the level of cultural beliefs regarding the efficacy of Aboriginal early childhood programs for their communities and their children. 


\section{Integrating processes}

A few years ago, Arlene had an enlightening conversation with teachers at the Mohawk-immersion Akwesasne Freedom School (ON, QC, NY). The response to a question on evaluating children's progress in the amazingly simple 3-page curriculum based on elements of the cosmos (see AFS, p. 323 below) was, "Well, we hear them talking in the hallways, don't we?" An early childhood educator from Cowichan Reserve's (BC) program told the story of her son coming home engaged and peaceful in contrast to his previous reaction of covering his ears after a conventional kindergarten day with "noisy little busy-bodies." A seamless and ongoing circle of "participatory evaluation" (Native Education Centre, 1991; Park, Brydon-Miller, Hall \& Jackson, 1993) has been documented for some time as consistent with many indigenous views of learning and human development and is reinforced in the INDIGENOUS FEEDBACK supplementing this paper. One critique cited the unexpected relevance of Reggio Emelia's European (Italian, subsequent to Montessori's innovations) approach to ECE which focuses on extended projects, environment-teacher-home relationships, and documentation as assessment and advocacy - eschewing the language of 'evaluation' apart from educational process (e.g., New, 2000). Even in the early days of debate over Head Start evaluations, a number of voices pointed to long-term and unanticipated consequences which escaped conventional 'measures', e.g., fewer placements in special education; fewer arrests, higher incomes, and longer marriages of adults (at least males) who had participated in Head Start (see Schweinhart, 1994; Schweinhart \& Weikart, 1993).

\section{METHODS AND MEASURES CRITIQUE}

In now critiquing some specific means of evaluation, we add methodological issues to the three major problems already laid out: (a) colonized research models which exclude relational participation among Aboriginal and other evaluators, their perspectives, and their tools, (b) confused purposes underlying Aboriginal child care and education which confound what is being evaluated, how, and why, and (c) isolated 'evaluation' as a disintegrated step in ECE processes.

Starting with the most conventional 'methods and measures' in use, we point to the long saga of debates over cultural bias in intelligence and achievement tests. A spin-off of this controversy was the attempt to find or define culture-free tests (e.g., Mercer \& Lewis, 1979). These tests, focusing on language-free geometric and mathematical concepts, proved to be as inappropriate for non-western children as the tests they were designed to replace. Researchers in this period largely came to realize that there is no way to formulate a proper measurement method while ignoring the cultural 
basis for such tests or tasks (Bond, 1996). It was further recognized that the institution of testing itself was a western cultural artifact. Whether penciland-paper or oral, it is the normative procedure in western culture for an authority figure to pose a series of questions with set answers to a student who is supposed to consider these questions as a chance to display abilities in isolation from any real life issue (Morawski, 1997). This kind of assessment - with its inherent power differentials, behavioural and statistical norms - epitomizes the colonial mindset that continues to plague us all and particularly alienate and disrespect Aboriginal peoples.

\section{REVISITING STANDARDIZED TOOLS}

Every standardized test is designed to work in a particular context. Results of standard tests are distorted in communities where children are taught to be cooperative versus being competitive. Aboriginal children may not be accustomed to working within strict time limits, or working in isolation from peers. There is evidence that children obtain higher test scores when tested by personally familiar examiners. Many children feel uncomfortable responding to questions that seem to be irrelevant or giving answers they believe the examiner knows. Despite these widely acknowledged problems, evaluation procedures still widely include the first type of tests below.

\section{Tests and intelligence}

Standard IQ tests are problematic in that they often give misleading or unusable results for 'minority' children. Two common IQ tests for young children are the Kauffman ABC and the Wechsler Preschool and Primary Scale. Both these tests have been shown to lead to mistaken labeling of minority American children as in need of 'special education' (Kerr, 1986). IQ tests such as these and tests of general scholastic aptitude or academic proficiency rest on questionable assumptions about human abilities.

The first assumption is that there exists a single general mental ability (the long-discussed " $g$ factor" of Spearman, 1927). The second assumption is that this capacity is the main determinant of academic success (e.g., Jensen, 1980), and thus important for society. The third assumption is that this general capacity is measured by standard tests. The fourth assumption is that the cultural basis of these tests can be eliminated. All of these assumptions should be questioned generally, but particularly for Aboriginal children.

1. Is there one intellectual capacity? Psychologists in fact disagree about whether there is a single thing called "intelligence." Horn and Cattell (1967) proposed two types of intelligences: fluid and crystalized. Thorndike (1927) thought of intelligence as being composed of several independent elements, each representing different abilities. Gardner $(1983,1999)$ has outlined a theory of up to 11 "multiple intelligences" including the math- 
ematical, artistic, interpersonal, and existential. Sternberg (1988, 1990) and his colleagues (Sternberg \& Grigorenko, 2000) have also been developing multi-factored and multi-metaphoric models of intelligence. Such views throw the value of generalized tests into great question as potential tools for Aboriginal and all early childhood programs.

2. Do IQ scores predict school success? Y'es, to some extent they do, but only because similar subsets of human skills are being measured by the intelligence tests as by the tests used in schools. This may mean that such tests have limited relevance outside of 'school.' One psychologist, McClelland (1976), argued some time ago that "neither the tests nor school grades seem to have much power to predict real competence in many life outcomes, aside from the advantages that credentials convey on the individuals concerned" (p.56).

3. \& 4. The assumptions that 'ability,' 'smartness,' 'wisdom' can be measured, and measured universally across cultures, are challenged throughout this paper (for some past critiques of cultural 'fairness' in IQ tests see Bernhard, 1990; Cummins, 1980, 1987; Kincheloe, Steinberg \& Gresson, 1997).

\section{Observation checklists and rating scales:}

Numerous observational checklists and rating scales have been developed as alternatives to tests: All these tools aim at better overall whole child evaluation. One of the most common tests used by researchers in Head Start evaluations is the Child Observation R.ecord (COR) (High/Scope Educational Research Foundation, 1992; also see Schweinhart \& Weikart, 1993). The COR is divided into six scales as follows: Initiative, Social Relations, Creative Representation, Music and Movement, Language and Literacy, Logic and Mathematics. It is important to note that the COR is based on Developmentally Appropriate Practice (DAP) as defined officially by the National Association for the Education of Young Children (Bredekamp \& Copple, 1997).

The judgment of 'appropriate' as made by this American professional group has not been substantially responsive to cultural diversity.

The revised edition of DAP in 1997 was motivated, in part by a recognition of the increasing cultural, racial and linguistic diversity of the population. Nevertheless, we argue that the guidelines are still based on the premise of universal notions of human developmerit. Diversity is introduced as a separate component within a model that privileges universal assumptions (Bernard, Gonzalez-Mena, Chang, O'Loughlin, Eggers-Pierola, Roberts Fiati, \& Corson, 1998). Therefore, we make the following fundamental criticisms. Although DAP encourages practitioners to consider the possible influence of culture, that is insufficient for widespread use in a diverse range of 
communities. Psychologists talking of developmental appropriateness still generally assume that the current western child-development knowledge base holds true for all children. Instead, it is our view that the foundational and defining role of cultural context must be recognized as a first step for meaningful assessment. It is a mistake to treat cultural context as an influence on a so-called universal pattern, and this mistake harms 'minority' children.

COR is based on a Piagetian perspective which prizes increased personal independence and rationality (Bernhard, 1995; O'Loughlin, 1992). These are clearly the standards of mainstream culture. Theorists such as Vygotsky and Bakhtin, in contrast, have tended to look toward the socio-historical and sociocultural context of development (O'Loughlin, 2001; Bernhard, 2003; Wertsch, 1991). Those following Vygotsky's (1978) approach consider the 'zone of proximal development' - a concept of emerging socially contextualized abilities at variance with a model based on personal autonomy. Below we further detail our arguments as to why COR is inappropriate as an across-the-board tool for the evaluation of early care and education settings.

\section{Dynamic assessment}

A third type of evaluation is based on dynamic assessment models ( $\mathrm{Lid} z \&$ Pena, 1997). Such tests present a learning experience where the tester observes what the child has learned under the best possible circumstances. Although the testing format is promising, there can be problems with such approaches. For example, in the Learning Potential Assessment Device (Feurestein, 1979), the examiner presents a task to a child and tests her on that task. He then teaches the child and tests again. The test is highly individual and this can hamper performance of children who are accustomed to group work. Extreme cases of examiner familiarity can also make it difficult to determine if the child's improved score is due to the examination condition or to the testers' biased scoring of similar examinee performance. Altogether, cultural conceptions of teaching and performance are not addressed.

\section{Child observation record: Critique and gaps}

We end this revisiting of standardized tools with particular criticism of key scales in the COR - the most prominent ECE evaluation measure.

The Initiative section, based on the DAP document, prizes the individual child's assertion and initiative above other qualities. The first two items in this section are "expressing choice to others," and "indicating a desired activity or place." The assumption that children should make verbal re- 
quests and express themselves in this particular way is highly individual and culturally specific.

The third Initiative item, "engaging in complex play," does not recognize that in some cultures simply observing others and their activities may be a high-level engagement process. In the Social Relations section the child receives credit for initiating interactions with adults although this can be inappropriate within some cultural standards. Similarly the verbalization of feelings is prized here-again, a particularly western mainstream value.

The COR section on Language is centered around a single language and focused on reading and writing. Even the section on speaking is reflective of DAP - complexity of a story and its details are valued most. The most advanced item in this section, for example, states "Child makes up and tells well-developed, detailed stories, rhythms or songs." If a child tells a traditional indigenous story, using valued open-ended discourse, this may not be judged complex and "well-developed" and thus the child will be misrepresented in test scoring.

The Logic and Mathematics portion of COR presents Piagetian tasks such as sorting, arranging, sequencing, comparing, and counting. All these depend on artificial, isolated tasks that are not contextual or related to meaningful behaviour.

Further, there are some important gaps in the COR where areas of languages, identity, and social interaction do not honour the unique complexities and variations in life histories of Aboriginal children. Some children in urban communities will have intimate contact with non-Aboriginal culture or may have families with non-Aboriginal parents and caregivers. Some may speak only English or French, or English and/or French and an Aboriginal language to varying degrees. Dialects and intermixings of these languages will exist. Some children from more remote communities will have known only their home language and their home village while others elsewhere may have moved often, living both on- and off-reserve. A sense of Aboriginal identity may have been with some children from birth, while others may just be learning of their Aboriginal heritage and what that might mean. Some may feel special and loved as Aboriginal children, while others have lives facing discrimination, alienation, sometimes violence, and other difficulties. Some Aboriginal children already have many traditional life skills, while in other communities children have fears of rural or wilderness situations. Yet other children may be uncomfortable with buildings and crowds of a city.

While COR remains accepted where ncrmative individual evaluations are valued, it does not touch on local and group goals - particularly cross-age/ generational interactions - of significance to indigenous communities. COR 
does not recognize that "the basic unit of analysis is no longer (the properties of) the individual, but ... sociocultural activity involving active participation of people in socially constituted practices" (Rogoff, 1990, p. 14). Here is where intense major re-thinking of 'good care' in indigenous terms is most needed.

\section{LOCAL GOALS OF DEVELOPMENT}

Local goals are central to the issue of appropriate evaluation in any early childhood program and particularly in Aboriginal situations. "Each of us lives out our species nature only in a specific local manifestation (Shore in Rogoff, 1990, p. 11)... . Progress must be defined according to local goals, with development in specific domains specified by cultural as well as biological goals and problems. Each community's valued skills constitute the local goals of development" (Rogoff, 1990, p. 12). In varying degrees, mainstream 'success' may be a variable local goal. It is critical to some communities and a matter of indifference to others as compared with success in the home community. An evaluator who proposes to use 'off-the-shelf' tools must consider the values underlying the tools. Those who would use the tools must consider the degree to which the tools may be dominated by standard school skills regardless of local goals. Critical aspects of a local goals perspective on evaluation include the following.

\section{Developmental domains}

Evaluation must consider domains that are recognized in the local communities. For example, the separation of thinking skills from emotional perceptiveness or separation of spirituality from any domain of life may not make sense for some communities. The definition of the overall concept of human "intelligence" (or achievement) in the particular community must be determined (e.g., Bernhard, 1995; Bernhard, 2001; O'Loughlin, 1992; Senior, 1993) through intensive interpretive interaction. "Development proceeds in a variety of directions with some important commonalities as well as essential differences in the routes taken toward the local goals that are sought in a particular community" (Rogoff, 1990, p. 12).

\section{Languages}

Language is a particular focus and the content of much child development schooling and evaluation. Since every language carries with it a culture, it is important to consider the issue of indigenous language and English use in evaluation. There are two dilemmas: it may be problematic to use English as the language of testing, and translation of English tests into Aboriginal languages often results in inappropriate and incomprehensible tools. Yet the alternatives are unclear. In some communities children's acquisition of the 
indigenous language is the ultimate priority of their parents (e.g., independent Aboriginal language immersion programs). In other situations the goal is the limited knowledge of certain ceremonial indigenous language elements. For some families Aboriginal language acquisition may not be a dominant goal but rather their childreri's competence in other indigenous cultural skills which are carried out in English.

ORAL AND WRITTEN LITERACIES. The question of oral heritage and oral fluency is important where much of a culture's heritage has not been written locally or by or with outsiders. The use of writing in the community may be specialized to signs and other practical purposes and not used for casual communication, entertainment, or general information. As well, there may be more than one literacy in the community, even in the same language, specialized for school, religious, informal and other particular purposes. Further, the high value placed on mainstream literacy in some early childhood and school programs may inappropriately de-value and interfere with children absorbing the richness of an oral tradition. Oral or written, formal patterns used in teaching may not recognize different styles of narrative expression and explanations (e.g., using a story to answer a direct question; a leading observation rather than a final 'moral').

CULTURAL NEGOTIATION. In many domains, epitomized by varying and emerging language goals, issues of cultural negotiation among and within communities require careful attention (Stairs, 1994. 1996). In one instance parents complain that the indigenous language is no longer heard much inside the school due to an emphasis on written products; in other instances adults complain that their children lose their memory for important teachings once they are written down and taught 'literally.' Conversely some elders have maintained that respect demands their oral knowledge now "be recognized in paper" by government and educators. Some communities have demonstrated a form of collective (rather than individual) writing which functions as group communication and problem solving. Numerous Aboriginal cultural groups have generated textual forms that integrate writing with diagrams, traditional motif page borders, collage and other designs (see e.g., Annahatak, 1985; CBC, 1988; Krupat, 1992 and much recent work in progress). Perhaps for some children, the local developmental goal is beginning mastery of multiple forms of language use rather than of standard language competence. In any case, goals are likely to be highly diverse across different Aboriginal groups and communities and to be variable even within communities (e.g., Chambers Erasmas, 1989; Scollon \& Scollon, 1981; Shearwood, 1987; Skutnabb Kangas, 1981).

\section{Learning styles}

Individual and group learning styles have an immediate impact on evaluation (Battiste \& Barman, 1995; Philips. 1983; Stairs, 1991, 1994). While 
arguments range over simplified and often dichotomized stereotypes in much of this work, some level of consensus emerges around certain basic issues. The importance of observation for Aboriginal children is one example. Traditionally Aboriginal children learn through observation of a skill (e.g., tulle mat weaving, midwifery, storytelling, even literacy activities; see Lave \& Wenger, 1991). Often this involves beginning with a nearly finished product (pants, boots) and working backwards into mastering all aspects of their creation (see e.g., Hornberger,1998; Lave \& Wenger,1991). In typical preschooling, on the other hand, skills such as these are often decontextualized into linear steps and separated so that the holistic learning is not apparent (Greenwood-Church \& Shawana,1998).

\section{Learning-teaching paradigms}

Vygotsky's (1978) concept of acquisition of knowledge involves collaborative interactions with older and younger children scaffolding each other. In this sense, it is not desirable for a person to outshine others. In such a situation, individual testing may not be appropriate. Yet the complexity of the issues is such that an Aboriginal student must be competent in the skills and knowledge that will allow them to be successful in both the community of their birth and broader Canadian society.

Converging commentaries from diverse indigenous communities emphasize a number of fundamental learning-teaching paradigms seldom voiced in western pedagogical literature nor addressed in developmental assessment tools. We illustrate here using excerpts from Cajete's (1994) Outline of indigenous teaching and learning orientations (p. 222-227).

Indigenous teaching focuses as much on learning with the heart as on learning with the mind. ... Indigenous teaching facilitates learning how to see who one really is, rather than an image manufactured... This real perception of self helps the student to realize that they are essentially responsible for the barriers to their own learning.... Through facilitating this constant examination of what students think they know, they remain open to new dimensions of learning. ... The nature and quality of relationship and perseverance through time determine the outcome of a teaching process.... Indigenous teaching is based on the nature and quality of communication at all levels of being. ... Service is the basis of the relationship between teacher and student. . . . Indigenous teachers recognize that work invites concentration and facilitates a quietness of mind. ... 'Each person's work' is honored. . . each student is unique and has a path of learning. . . . Busy work is not a concept. . . Ritual, mythology, and the art of storytelling - combined with the cultivation of relationship to one's inner self, family, community, and the natural environment - are utilized to help individuals realize their potential for learning and living a complete life. This is the legacy of Indigenous people. It is imperative that its message and its way of educating be revitalized for Life's sake. (See also Annahatak, 1985; Kawagly, 1990) 


\section{Participation and situated learning}

It is important to recognize that all learning is situated and constituted within "communities of practice" (Lave: \& Wenger, 1991; Wenger, 1998). Situated learning theory draws our attention to practice and to implicit or tacit knowledge; such knowledge is rarely acknowledged or 'measured' in formal or standardized testing. Further, situated learning theory would suggest, in part, that we assess a learning situation as a whole rather than a focus on isolated children. What is going on? What patterns of interaction between children, teachers and other players, and in what activities? It is the forms of participation underway which are observed and the resources allowing for meaningful participation. This is a radical departure from standard child observation approaches and instruments, but has been used to reveal much.

To illustrate, McDermott (1993) studied a child who was considered learning disabled. Much of the observed "disability" revolved around social dynamics in the classroom, rather than the child himself. Rogoff and colleagues (1993) worked with mothers and young children from several cultures, including indigenous Mayan, in play situations. They describe varying forms of guiding participation by the adults, including their degree of management and their reactions to their children's success. A child's learning in relation to adult structures, promises and rewards, for instance, would not be perceived if the child were observed individually in an unfamiliar context. Related work involving teachers as well as parents in interactions with their children has been described in a number of North and Latin American communities (see Chavajay, DeHaan, Meija-Arauz, Paradise $\&$ Stairs in CSR, 2000).

Situated learning also implies attention to concrete, contextually appropriate, and culturally meaningful tasks and tools or artifacts. Cole's (1990, 1996) examples with Liberian children are illustrative of this limitation in western standardized evaluation extending to even the observational COR. The African children in Cole's study were apparently unable to judge quantity and proportion using American mathematical objects. When bowls of rice were used, familiar and important material carrying life and commerce, they were highly accurate.

Colorado (1988) stresses the significance of participatory research in bridging the "gap between native and non-native" which "could become a powerful catalyst towards broad social change, justice and quality in our backyard" (p. 62). She points to the similarity between participatory research [including evaluation] and "relations" in Native science, and to the participatory philosophy of dialectical thinking as a nexus for decolonizationincluding a "trustworthiness" sense of validity linking Native and some emerging qualitative western approaches to knowledge, and so to evaluation (see Lincoln, 1995, Lincoln \& Guba, 2000, Heron \& Reason, 1997). 


\section{SPECULATION ON ALTERNATIVES}

In conclusion, we have taken the stand that there is no simple way to appropriate or to adapt mainstream evaluation tools without doing serious injustice to indigenous communities. Nonetheless the communities themselves as well as outside agencies do require evaluation as to the efficacy of program delivery based on local constellations of community and 'global' (Dei, Hall \& Rosenberg, 2001) goals. We offer in closing just a few suggestive speculations toward alternatives in addressing such evaluation needs. Each suggestion rests on the assumption of Aboriginal community diversity and uniqueness - historically, geographically, linguistically, socio-economically, politically, spiritually. Elaboration of such speculations into the 'how' of evaluation practice is seen as a long-term community-based process, always remembering to ask the 'why' and the 'who' underlying any early childhood educational or other program. What is culturally and personally understood as 'good care;' how, why, and who are we becoming - as indigenous and world community members-by choosing certain approaches and practices in ECE? This essential question must be asked about each possibility such as the tentative ones below, and it is also a powerful answer to challenges of "anything goes" relativism from ECE evaluators who are tied to a universalistic illusion of human development (J.K. Smith, 1992):

- Community focus groups (education councils and/or others concerned)

- Key individuals (elders, caregivers, healers, creative cultural and political leaders, experienced informal educators and school teachers, and others from whom community advice is regularly sought)

- Local curricula (study of materials, programs, value statements regarding schooling such as are being developed in some Aboriginal communities)

- Child histories (attention, with alertness to all social implications, to particular children "doing well" or "in difficulty" in the eyes of teachers, parents, others)

- Parent reflections (family comments on learnings from preschool which either make them happy or disturbed about their children)

- Languages/Literacies surveys (local usage and goal studies)

- Child interaction observations and engaged activity ['participant observation' in conventional research language] (play, family, school, and other situational descriptions of participation).

\section{A narrative stance}

In any efforts such as these, all involved (Aboriginal and North/South EuroAmerican) in our "considerations for evaluating 'good care' in Canadian Aboriginal early childhood settings" espouse in their particular ways a 
deeply narrative stance. More meaningful and trustworthy insights into children's lives come from the stories they and their caregivers, teachers, family and community members tell than from test or observation 'scores,' as evidenced in a flood of recent research (e.g., Ada, 2003; Clandinin \& Connelly, 2000; Egan, 1986; Gallas, 1994; Thomas,1995). Narrative arises from trouble, quandary, difference vis-à-vis dominant societal norms-the 'canon' - and works at making cultural meaning and personal identity uniquely real and valued (Bruner, 1990). Questions of generalization need to be re-thought as evaluators accept the local nature of developmental goals (e.g., Lincoln, 1995). The use of story in research with teachers and educational practice, with curriculum and children has developed a strong base over the past decade or so (see Polkinghorne, 1988 regarding the use of narrative generally in human development research).

Karen Gallas says of children's stories: "When children are continually offered opportunities to express their stories about the world through many avenues ... they create new kinds of learning communities that offer membership to every child; they teach us that the process of education transcends methodology and curriculum" (pp. xvi-xvii). She says of teachers' stories: "Teachers tell stories about their classrooms. . . . each story, although not a fiction, presents many perspectives and many meanings rather than one focus and conclusive meaning" (p. 2). Community members also often offer their goals and future visions in the form of stories-their sense of possibility and imaging things other than they are. The attention of early childhood education evaluators to this rich source of 'data' particularly central to indigenous thought and expression (e.g., Chambers Erasmus, 1989) - may convey a great deal about local concerns. Accounts of positive events, problems and changes for children, families and communities linked to ECE programs could become part of guidelines for any sitebased indigenous child care and evaluation work.

\section{AUTHORS' FINAL WORDS}

We stress that Aboriginal ECE practices and reforms must return education of indigenous peoples, and its evaluation at any level, to their own hands, and keep it there.

\section{INDIGENOUS FEEDBACK}

This paper was discussed at the Canadian Society for Studies in Education Annual Meeting in 2001. Several participants, on returning home, shared the conference version of the paper with indigenous early childhood colleagues and students. We find it important to summarize their feedback which emphasizes and adds to certain key issues brought forth here. By mutual agreement, the commentators remain anonymous. 
Perhaps foremost, children are seen in diverse Aboriginal traditions as gifts from the Creator; they are cared for as the purpose of life. Care, education, is not bounded by schools or by mind-body-spirit fragmentations or by stages of life. From before birth (see Porter, 1993; 1993b) until after death children are a sacred legacy on loan to parents by the Creator.

Very simply and directly we are told that the foundation for early childhood care and education is spiritual - not ultimately material, however much of the ways and means towards worldly surviving and thriving are expressed on the surface of program purposes. Various explicit expressions of this foundation come from the Iroquian Thanksgiving Address used as month-bymonth "curriculum" generated by the elements of the cosmos (AFS, n.d.) earth, plants, crawlers, water and its beings, four-legged, humans, the skyworld and Creator - and from Cree and other First Nations' use of the medicine wheel guiding the four elements of learning and becoming (see Goulet $\&$ McLeod, this issue).

Children must be known, taught, and 'evaluated' if the reason is clear, holistically, over time, in a variety of contexts and through many meanstaking into account both 'school' and 'community' knowledges. Evaluation is seen as a process integral with research and teaching, narrative in nature whereby meaning and understanding are arrived at together. Such process highlights time - the time to get to know; the assumption that programs and children and communities are dynamic and changing. One teacher spoke of herself as a lifetime learner in ECE; the need not to come in for just halfan-hour but to really interact and communicate, and she with another colleague stressed the need to operate on a personal level. Both teachereducation and child programs that are relation-based and informal manifest this attitude.

Power was discussed in the context of early childhood education, and the need to recognize different types of power - power of cultural and personal identity as well as political and socio-economic power - and the fluidity of power when programs are authentically seen to be unfolding as all learn. Indigenous educators must be aware of power issues between adults and children, between school and tradition, among cultures.

Practical living concerns were voiced as critical to childhood educational processes, not as trivial details, much as in Maracle's (this issue) analysis of adult indigenous language programs. Internally fragmented political issues scatter a community's ECE program efforts. Parents' alienation based on their own assimilative, abusive, or otherwise negative schooling experiences must be perceived and dealt with slowly and carefully - not with unreflective critical judgements. More elder input was often mentioned, and more use of all local community resources. The preparation of indigenous teachers was 
repeatedly emphasized above other needs. Cleanliness and safety were noted as needing mindful attention.

From the situations offering feedback came a strong interest in other cultural ways of early childhood care and education, both cross-Aboriginal and cross-cultural generally. One student dubbed her instructor's tapes of other ECE programs as "awesome." In closing we cite an indigenous actionresearch report, looking broadly at conceptions of community 'health,' which replaced the term 'evaluation' with 'valuation' (ATFE, in progress). Valuation, with that little device of dropping the ' $E$ ', carried layers of meaning relevant to 'good care' in childhood and beyond. Valuation implies the celebration of community capacity without dependence/control, the founding of programs on basic values of the culture, the cyclic nature of local activity and reflection on its impact (research), and the ongoing vision - without (e)valuative endpoints - of any cultural renewal effort including early childhood care and education.

\section{NOTES}

1. In a recent review (Lee, 2002), we find an expanding use of the term 'evaluation' to include cognitive/cultural perspectives often unacknowledged in older (and even some current) paradigms that make distinctions between program evaluation, individual assessment, and the psychometric technology of measurement and testing (e.g., Klitgaard, 1995; Preskill, 1999; L.N. Smith, 1991). Here the term 'evaluation' is used in its large sense of addressing at multiple levels the multiple visions of indigenous early childhood education.

2. The term 'good care' was offered by Margo Greenwood as she reviewed this paper. It is the phrase she uses in her early childhood work at the University of Northern British Columbia and as Aboriginal Liaison in the Canadian Child Care Federation (<http:// www.cccf-fcge.ca/>).

3. Acknowledgement and thanks are given to Enid Elliot (Pacific Rim Early Childhood Institute), Linda Goulet (Saskatchewan Indian Federated College) and Kathryn McNaughton (University College of the Cerriboo) for sharing their follow-up conversations with indigenous early childhood educators. Several points from post-conference conversations with Arlene are also included, with thanks to Mohawk and other Aboriginal colleague-friends.

\section{REFERENCES}

Ada, A.F. (2003). A magical encountere: Latino children's literature in the classroom. Boston, MA: Allyn $\mathscr{G}$ Bacon.

AFS (Akwesasne Freedom School). (no date). Curriculum. Akwesasne, NY: Author.

AHS (Aboriginal Head Start) Subcommittee. (1996). Aboriginal head start: Program principles and guidelines. Ottawa, ON: Health Canada.

ATFE (Akwesasne Task Force on the Environtnent). (in preparation). First environment restoration Initiative/lakoti'satstenhesera: wis Ne Ohwentsia [They Strengthen the Earth]: Program (e)valuation. Akwesasne, ON, QC, NY: Author.

Annahatak, B. (1985, November). Philosophy of Inuit education. Paper prepared for Symposium ' 85 on Inuit Education, Kativik School Board, Kuujjuaq, Arctic QC (Nunavik). 
Battiste, M. \& Barman, J. (Eds.). (1995). First Nations education in Canada: The circle unfolds. Vancouver, BC: University of British Columbia Press.

Bernhard, J. K. (2003). Toward a $21^{\text {st }}$ century development theory: Principles to account for diversity in children's lives. Race, Gender, and Class, 9(4).

Bernhard, J. K. (1995). The changing field of child development: Cultural diversity and the professional training of early childhood educators. Canadian Joumal of Education, 20(4), 415-436.

Bernhard, J. K. (1990). Assessment of socio-culturally diverse students: Problems in special educational theory; implications for practice. Intemational Journal of Dynamic Assessment and Instruction, 1(2), 86-104.

Bernhard, J. K., Gonzalez-Mena, J., Chang, H.N., O'Loughlin, M., Eggers-Pierola, C., Roberts Fiati, G., \& Corson, P. (1998). Recognizing the centrality of cultural diversity and racial equity: Beginning a discussion and critical reflection on developmentally appropriate practice. Canadian Joumal of Research in Early Childhood Education, 7(1), 81-90.

Bernhard, J. K., Pollard, J., Eggers-Pierola, C., \& Morin, A. (2002). Infants and toddlers in Canadian multi age child care centres: Age, ability and linguistic inclusion. French version title: Les poupons et les jeunes enfants dans les garderies pour ages multiples. Research Connections Canada, 79-185.

Bond, L. (1996). Unintended consequences of performance assessment: Issues of bias and fairness. Educational Measurement: Issues and Practice, 14(4), 21-24.

Bredekamp, S. \& Copple, C. (Eds.). (1997). Developmentally appropriate practice in early childhood programs (Rev. Ed.). Washington, DC: National Association for the Education of Young Children (NAEYC).

Bruner, J. (1990). Acts of meaning. Cambridge, MA: Harvard University Press.

Cajete, G. (1994). Look to the mountain: The ecology of indigenous education. Durango, CO: Kivakí Press.

Cardinal, G. (Director). (1991). Tikanagan (video). In Tamarack Productions, As long as the rivers flow (video series). Toronto/Ottawa, ON: National Film Board of Canada.

CBC (Canadian Broadcasting Corporation) (1988, February 1,8). Literacy: The medium and the message. Ideas (transcript). Toronto, ON: Author.

Chambers Erasmus, C. (1989). Ways with stories: Listening to the stories Aboriginal people tell. Language Arts, 66(3), 267-275.

Clandinin, D. J. \& Connelly, F. M. (2000). Narrative inquiry: Experience and inquiry in qualitative research. San Francisco, CA: Jossey-Bass.

Colorado, P. (1988). Bridging native and western science. Convergence, 21(2/3), 49-68.

Cole, M. (1996). Cultural psychology: A once and future discipline. Cambridge, MA: Belknap Press of Harvard University Press.

Cole, M. (1990). Cultural psychology: A once and future discipline? In J. J. Berman (Ed.), Nebraska Symposium on Motivation 1989: Cross-cultural perspectives. Lincoln, NB: University of Nebraska.

Comité pédagogique de construction. (1974). Where we want our children to be led. Povungnituk, Arctic QC (Nunavik): Ecole Elémentaire et Secondaire.

Commissioner's Office of Research and Evaluation \& Head Start Bureau, US Department of Health and Human Services (2000, Aptil). Celebrating cultural and linguistic diversity in Head Start. Washington, DC: Author.

Cummins, J. (2001). Negotiating identities: Education for empawerment in a diverse society (2 ${ }^{\text {nd }}$ ed.). Los Angeles: California Association for Bilingual Education.

Cummins, J. (1987). Psychoeducational assessment in multicultural school systems. Canadian Joumal of Exceptional Children, 3(4), 115-117. 
Cummins, J. (1980). Psychological assessment of immigrant children: Logic or intuition? Journal of Multilingual and Multicultural Development, 1, 97-111.

CSR (Conference for Sociocultural Research[3rd International]). (2000, July). Symposium: Cultural Patterns in Teaching and Learning: The Drganization of Participation and Observation. Campinas/Sao Paulo, Brazil.

Dei, G. J. S., Holmes, L., Mazzuca, J., Mclsaac, E., \& Campbell, R. (1995). Drop out or push out? The dynamics of Black students' disengagement from school. Toronto: Ontario Ministry of Education.

Dei, G.J.S., Hall, B.L. I Rosenberg, D.G. (Eds.). (2000). Indigenous knowledges in global contexts: Multiple readings of our world. Toronto, ON: University of Toronto Press.

Driscoll, A. (1995). Cases in early childhood education: Stories of programs and practices. Boston, MA: Allyn \& Bacon.

Egan, K. (1986). Teaching as story telling: An alternative approach to teaching and curriculum in the elementary school. London, ON: Althouse Press.

Feuerstein, R. (1979). The dynamic assessment of retarded performers: The leaming potential assessment device, theory, instruments, and techniques. Baltimore, MD: University Park Press.

Gallas, K. (1994). The languages of learning: How children talk, write, dance, draw, and sing their understanding of the world. New York, NY: Teachers College Press.

Gardner, H. (1993). Frames of mind: The theory of multiple intelligences. New York, NY: Basic Books.

Gardner, H. (1999). Intelligence reframed: Multipks intelligences for the $21^{\text {st }}$ century. New York, NY: Basic Books.

Grant, A. (1996). No end of grief: Indian residential schools in Canada. Winnipeg, MA: Pemmican.

Goulet, L., Dresseyman-Lavallée, M. \& McLeod, Y. (2001). Early childhood education for Aboriginal children: Opening petals. In K. P. Binda with S. Calliou (Eds.), Aboriginal education in Canada: A study in decolonization (pp.147-153). Missassauga, ON: Canadian Educators' Press.

Greenwood, M. (2001). BC First Nations community evaluation guide. Vancouver, BC: First Nations Inuit Health Branch.

Greenwood-Church, M., \& Shawana, P. (1998). Quality child care in aboriginal communities. Paper presented at the Canadian Child Care Fedcration Conference, Banff, AB.

Health Canada. (1996). Aboriginal Head Start Initiative Newsletter, 1(1), 1-7.

Health Canada. (1995). Aboriginal Head Start initiative: Guide for applicants. Ottawa, ON: Author.

Health Canada. (1994). Aboriginal Head Start resources guide. Ottawa, ON: Author.

Heron, J. \& Reason, P. (1997). A participatory inquiry paradigm. Qualitative Inquiry, 3, 274-294.

High/Scope Educational Research Foundation (1992). High Scope Child Observation Record for Ages 2 1/2-6 (COR). Ypsilanti, MI: Author.

Horn, J. L. \& Cattell, R. B. (1967). Age differences in fluid and crystallized intelligence. Acta Psychologica, 26, 107-129.

Hornberger, N. H. (1998). Misbehavior, punishment, and put-down: Stress for Quechua children in school. Language and Education, 2(4), 239-253.

Jensen, A. R. (1980). Bias in mental testing. New Y'ork, NY: Free Press.

Kawagley, O. (1990). Yup'ik ways of knowing. Canadian Joumal of Native Education, 17(2), 5-17.

Kerr, M. (1986). Native American and non-Native American performance differences on the WISC$R$ and K-ABC. Paper presented at the American Educational Research Association Annual Meeting, San Francisco, CA. [ERIC Document No. ED 269481 ]. 
Kincheloe, J. L., Steinberg, S. R., \& Gresson, A. D. (1997). Measured lies: The bell curve reconsidered. New York, NY: Saint Martin's Press.

Kingsolver, B. (1993). Pigs in heaven: A novel. New York, NY: HarperCollins.

Klitgaard, R.(1995). Including culture in evaluation research. In R. Picciotte \& R.C. Rist (Eds.), New Directions for Evaluation, 67, 135-146.

Krupat, A (Ed.). (1992). New voices in Native American literary criticism. Washington, DC: Smithsonian.

Lave, J. \& Wenger, E. (1991). Situated learning: Legitimate peripheral participation. New York, NY: Cambridge University Press.

Lee, M. W. (2002). An investigation of cultural dimensions and their influence on collaboration and program theory in one cross-cultural context. Unpublished doctoral dissertation, Queen's University, Kingston, $O N$.

Lidz, C. S. \& Pena, E. D. (1997). Dynamic assessment: The model, its relevance as a non-biased approach and its application to Latino American preschool children. Language, Speech, and Hearing Services in the Schools, 27(4). 367-372.

Lincoln, Y.S. (1995). Emerging criteria for quality in qualitative and interpretive inquiry. Qualitative Inquiry, 1(3), 275-289.

Lincoln, Y. S. \& Guba, E. (2000). Paradigmatic controversies, contradictions, and emerging confluences. In N. Denzin \& Y. S. Lincoln (Eds.), Handbook of qualitative research ( $2^{\text {nd }} \mathrm{Ed}$.) (pp. 163-188). Thousand Oaks, CA: Sage.

McClelland, D. C. (1976). Testing for competence rather than for "intelligence." In N. J. Block \& G. Dworkin (Eds.), The IQ controversy. New York, NY: Pantheon,

McDermott, R.P. (1993). The acquisition of a child by a learning disability. In S. Chaiklin \& J. Lave (Eds.), Understanding practice: Perspectives on activity and context (pp. 269-305). Cambridge, UK: Cambridge University Press..

Mercer, J. \& Lewis, J. F. (1979). System of multi-cultural pluralistic assessment (SOMPA). New York: The Psychological Corporation

Morawski, J. M. (1997). White experimenters, white blood, and other white conditions: Locating the psychologist's race. In M. Fine, L. Weis, L. C. Powell, \& L. M. Wong (Eds.), Off white: Readings on race, power and society. New York, NY: Routledge.

Native Education Centre (1991). Discovering the knowledge in the community: Using participatory evaluation. Vancouver, BC: Author.

New, R. (2000). The Reggio Emelia approach: It's not an approach - it's an attitude. In J. Roopnarine \& J. Johnson (Eds.), Approaches to early childhood education. Columbus, $\mathrm{OH}$ : Merrill.

O'Loughlin, M. (2001). Seven principles underlying socially just and ethnically inclusive teacher preparation. in S. H. King $\&$ L. Castanel (Eds.), Racism and racial inequality: Implications for teacher education. Washington DC: American Association of Colleges of Teacher Education.

O'Loughlin, M. (1992). Rethinking science education: Beyond Piagetian constructivism toward a sociocultural model of teaching and learning. Journal of Research in Science Teaching, 29, 791-820.

Park, P., Brydon-Miller, M., Hall, B. \& Jackson, T. (Eds.) (1993). Voices of change: Participatory research in the United States and Canada. Toronto, ON: OISE Press.

Pence, A., Kuehne, V., Greenwood-Church, M., Opekokew, M.R. \& Mulligan, V. (1992). First Nations early childhood care and education: The Meadow Lake Tribal Council/School of child and youth care curriculum development project. Multiculturalism, 14(3/3), 15-17.

Philips, S. U. (1983). The invisible culture: Communication in classroom and community on the Warm Springs Indian reserve. New York, NY: Longman. 
Polkinghorne, D. E. (1988). Narrative knowing and the human sciences. Albany, NY: SUNY Press. Porter, T. (1993b). Child rearing methods according to Mohawk traditions. Cornwall, ON: KAV Productions / St. Regis Drug \& Alcohol Division. (Video).

Porter, T. (1993b). Pregnancy and birth according to Mohawk traditions. Cornwall, ON: KAV Productions / St. Regis Drug \& Alcohol Division. (Video).

Preskill, H. (1991). The cultural lens: Bringing utilization into focus. In C.L. Latson \& H. Preskill (Eds.), New Directions in Progtam Evaluation, 49, 5-16.

RCAP (Royal Commission on Aboriginal Peoples). (1996). Gathering strength, Report (Vol 3). Ottawa, ON: Canada Communication Group.

Rogoff, B. (1990). Apprenticeship in thinking: Cognitive development in social context. New York, NY: Oxford University Press.

Rogoff, B., Mistry, J., Göncö; A. \& Mosier, C. (1993). Guided participation in cultural activity by toddlers and caregivers. Monographs of the Society for Research in Child Development, 58(8, Serial No. 236).

Schweinhart, L. (1994). Lasting benefits of preschcol programs. ERIC Digest, Washington, DC: Office of Education Research and Improvement [ERIC Document No. ED 365 478].

Schweinhart, L. \& Weikart, D. (1993). Success by empowerment: The High/Scope Perry preschool study through age 27. Young Children, 49(1), 54-58.

Scollon, R. \& Scollon, S. K. (1981). Narrative, literacy and face in interethnic communication. Norwood, NJ:Ablex.

Senior, S. (1993). Canadian Native intelligence studies: A brief review. Canadian Journal of Native Education, 20(1).

Shearwood, P. (1987). Literacy among the aboriginal peoples of the Northwest Territories. Canadian Modern Language Review, 43(4), 630-642.

Skutnabb-Kangas, T. (1981). Bilingualism or not. Clevedon, Avon, UK: Multilingual Matters.

Smith, J. K. (1992). Interpretive inguiry: A practical and moral activity. Theory into Practice, $31(2), 100-106$.

Smith, N. L. (1991). Evaluation reflections: The context of investigations in cross-cultural evaluations. Studies in Educational Evaluation, 17, 3-21.

Spearman, C. (1927). The abilities of man. New York, NY: MacMillan.

Stairs, A. (1991). Learning processes and teaching roles in Native education: Cultural base and cultural brokerage. Canadian Modern Language Revriew, 47(2), 280-294.

Stairs, A. (1994). Indigenous ways to go to school: Exploring many visions. Journal of Multilingual and Multicultural Development, 15(1), 63-76.

Stairs, A. (1996). Human development as cultural tregotiation: Indigenous lessons on becoming a teacher. Joumal of Educational Thought, 30(3). 219-239.

Thomas, D. (Ed.). (1995). Teachers' stories. Buckingham, UK/Philadelphia, PA: Open University Press.

Thorndike, E. L. (1927). The measurement of intelligence. New York, NY: Bureau of Publications, Teachers College, Columbia University.

Todd, L. (Director) (1991). The learning path (video). In Tamarack Productions, As long as the rivers flow (video series). Toronto/Ottawa, ON: National Film Board of Canada..

Tuhiwai Smith, L. (1999). Decolonizing methodologies: Research and indigenous people. London, UK: Zed Books.

Vygorsky, L. S. (1978). Mind in society: The development of higher psychological processes. Cambridge, MA: Harvard University Press. 
Wenger, E. (1998). Communities of practice: Learning, meaning, and identity. Cambridge: Cambridge University Press.

Wertsch, J. (1991). Voices of the mind: A sociocultural approach to mediated action. Cambridge, MA: Harvard University Press.

Xtria (formerly Ellsworth Associates) (2001, June). Annotated bibliography of Head Start research. McLean, VA: Head Start Research Library. <http://www.acf.dhhs.gov/programs/hsb2/biblio/>

ARLENE HOLLAND STAIRS is a cultural psychologist working particularly with indigenous communities, diverse ways of knowing, and relational, re-creative ways of inquiring. She collaborates in community and academic projects in various parts of Southern Canada, the Arctic, Mexico, and elsewhere, and teaches at Queen's University. She has published in, and guest-edited for, a number of journals and contributed several book chapters on her work.

JUDITH K. BERNHARD is an early childhood instructor and researcher at Ryerson Polytechnic University and currently a Fulbright Scholar at Florida Atlantic University. She has conducted federally-funded investigations with immigrant and refugee children and their families. Enabled by her Latina background, she has published numerous ethnographic studies within Latino communities and is on the editorial board of Early Education and Development.

ARLENE HOLLAND STAIRS est une psychologue culturelle qui oeuvre particulièrement auprès des communautés autochtones, sur les divers modes de savoir et les modes de recherche relationnels et récréatifs. Elle collabore à des projets communautaires et universitaires dans différentes régions du Sud du Canada, dans l'Arctique, au Mexique et ailleurs et elle enseigne à l'Université Queen's. Elle a publié des articles en tant que rédactrice invitée dans un certain nombre de revues et a rédigé plusieurs chapitres d'ouvrage sur ses recherches.

JUDITH K. BERNHARD est instructrice et chercheuse sur la petite enfance à la Ryerson Polytechnic University, et elle fréquente actuellement la Florida Atlantic University avec une bourse Fulbright. Elle a réalisé plusieurs études subventionnées par le fédéral auprès des enfants d'immigrants et de réfugiés et leurs familles. Grâce à ses antécédents latinoaméricains, elle a publié de nombreuses études ethnographiques sur les communautés latino-américaines et fait partie du conseil de rédaction de Early Education and Development. 